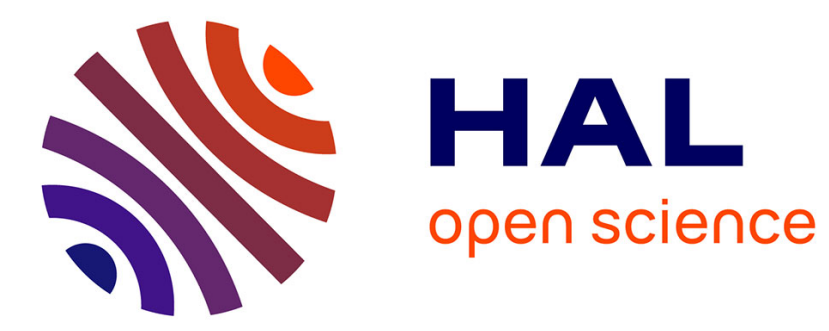

\title{
Effect of sowing date and variety on main shoot leaf emergence and number of leaves of barley and wheat
}

\author{
E. J. M. Kirby, Margaret Appleyard, Gwynneth Fellowes
}

\section{To cite this version:}

E. J. M. Kirby, Margaret Appleyard, Gwynneth Fellowes. Effect of sowing date and variety on main shoot leaf emergence and number of leaves of barley and wheat. Agronomie, 1985, 5 (2), pp.117-126. hal-00884740

\author{
HAL Id: hal-00884740 \\ https://hal.science/hal-00884740
}

Submitted on 1 Jan 1985

HAL is a multi-disciplinary open access archive for the deposit and dissemination of scientific research documents, whether they are published or not. The documents may come from teaching and research institutions in France or abroad, or from public or private research centers.
L'archive ouverte pluridisciplinaire HAL, est destinée au dépôt et à la diffusion de documents scientifiques de niveau recherche, publiés ou non, émanant des établissements d'enseignement et de recherche français ou étrangers, des laboratoires publics ou privés. 


\title{
Effect of sowing date and variety on main shoot leaf emergence and number of leaves of barley and wheat
}

\author{
E. J. M. KIRBY, Margaret APPLEYARD \& Gwynneth FELLOWES
}

Plant Breeding Institute, Trumpington, Cambridge CB2 $2 L Q, U K$

Rate of leaf emergence and number of leaves was measured on nine varieties of wheat and nine varieties of barley on four sowing dates in each of two years. Number of leaves declined the later the plants were sown, except for the February or March sowing when the number of leaves increased in the winter varieties. There were differences between varieties and a strong variety $\times$ sowing date interaction, which was probably due to differences in vernalisation response.

The rate of leaf emergence was faster the later the sowing date and there were differences between varieties. Analysis by regression of number of leaves on accumulated temperature showed that the rate was up to 80 per cent faster in the last sowing, compared with the first. Differences of up to 18 per cent were found between varieties, but there was little or no interaction with sowing date. Leaves of barley emerged more quickly than those of wheat.

There was a correlation between rate of leaf emergence and rate of change of daylength at the time of plant emergence, similar to that found by other workers. There was evidence that the base temperature varied with date of sowing.

Additional key words : Vernalisation, accumulated temperature, rate of change of daylength, base temperature.

Effet de la date de semis et de la variété sur le rythme d'apparition des feuilles du brin-maître et leur nombre total chez l'orge et le blé.

La vitesse d'apparition des feuilles et leur nombre ont été observés pour 9 variétés de blé et 9 variétés d'orge et pour 4 dates de semis au cours de 3 années successives. Le nombre final de feuilles diminue lorsque les dates de semis sont de plus en plus tardives, sauf pour le semis de février ou de mars pour lequel le nombre de feuilles est plus élevé chez les variétés d'hiver. On constate des différences entre variétés ainsi qu'une forte interaction variété $x$ date de semis, qui sont probablement liées à des différences de sensibilité à la vernalisation. La vitesse d'apparition des feuilles augmente pour des semis plus tardifs et varie entre variétés. L'analyse, par régression linéaire, des relations entre le nombre de feuilles et les sommes de température accumulées montre une plus grande vitesse d'apparition des feuilles, de l'ordre de $80 \%$, pour le semis le plus tardif par rapport au plus précoce. Les différences entre variétés vont jusqu'à $18 \%$, mais l'interaction entre la date de semis et la variété est faible à nulle. Le rythme d'apparition des feuilles est plus rapide chez l'orge que chez le blé. Ce rythme est corrélé à la vitesse de changement de la durée du jour au moment de l'apparition du pied, selon une relation comparable à celle constatée par d'autres auteurs. On montre que la température de base (ou seuil) varie selon la date de semis.

Mots clés additionnels : Vernalisation, température accumulée, vitesse de changement de la durée du jour, température de base.

\section{INTRODUCTION}

Leaf production of the cereal plant has been used to quantify both development and growth. For example the Zadoks growth stage scale, used extensively in Europe for timing herbicide and fertiliser treatments, uses expanded leaves on the main shoot as a criterion of development and other similar schemes have been devised (e.g. HAUN, 1973). In cereal growth studies considerable emphasis has been given to the importance of leaf area and its relation to growth and yield and models which seek to simulate growth and yield of cereal crops necessarily have sub-routines which produce leaf area growth, sometimes on an 
individual leaf basis (PORTER et al., 1982). While much information exists about leaf initiation, growth and emergence, recent field studies have revealed that there may be significant differences in rate of leaf emergence of plants sown at different dates throughout the normal sowing season (BAKER et al., 1980 ; KIRBY et al., 1982). These differences are not explicable in terms of differences in length of day and it has been suggested that the cereal plant may respond to differences in the rate of change of daylength (BAKER et al., 1980 ; KIRBY et al., 1982) which may affect temperature response or that sowing date may affect the base temperature for leaf emergence (KIRBY et al., 1982).

Genotypic differences in leaf emergence rates are also known and these have been used in breeding programmes to select for certain plant types (SYME, 1974). Selection and breeding studies in forage grasses have shown that leaf emergence rate is highly heritable and that considerable changes can be produced within relatively few generations (EDWARDS \& COOPER, 1963).

Because of the significance of leaf production, work was done to explore variation in leaf parameters in barley and wheat and to analyse the effect of genetic and environmental factors. Results from such analyses may provide the bases for analysis and prediction of leaf production using simulation techniques. In this paper we give data for wheat from two seasons which confirm that sowing date has a strong effect on the rate of leaf emergence and show that while there is genetic variation within both wheat and barley, there is little interaction between variety and sowing date so that genetic differences in rate may be expressed over a wide range of environments.

\section{MATERIALS AND METHODS}

\section{A. Experimental design}

The experiments were done at the Plant Breeding Institute (Latitude $52^{\circ} 11^{\prime}$ ) with wheat in $1980 / 81$ and $1981 / 82$ and with barley in $1979 / 80$ and $1980 / 81$. In each year there were 4 sowing dates (table 1). Several genotypes were grown in each year of the experiment (table 2). In the wheat experiment most were commercial winter varieties with a vernalisation response, but also included were 'Fenman', 'Highbury', 'Wembley' and a winter barley variety, 'Igri'. Most of the barley genotypes were commercial winter varieties or advanced breeding lines of winter types. Some of the results for the barley experiments have been reported (KIRBY et al., 1982). The experiments were organised so that each year $\times$ species combination formed a separate unit each with the same experimental design.

TABLE 1

Dates of sowing of experiments described in the text

Dates de semis des expérimentations décrites dans le texte

\begin{tabular}{|c|c|c|c|c|c|}
\hline & & \multicolumn{4}{|c|}{ Sowing } \\
\hline & & 1 & 2 & 3 & 4 \\
\hline $1979 / 80$ & Barley & 12 Sep & 17 Oct & 21 Nov & $19 \mathrm{Feb}$ \\
\hline $1980 / 81$ & Barley & 18 Sep & $15 \mathrm{Oct}$ & $12 \mathrm{Nov}$ & $17 \mathrm{Feb}$ \\
\hline $1980 / 81$ & Wheat & $10 \mathrm{Sep}$ & $24 \mathrm{Oct}$ & $4 \mathrm{Dec}$ & 25 Feb \\
\hline $1981 / 82$ & Wheat & 10 Sep & $14 \mathrm{Oct}$ & 18 Nov & $8 \mathrm{Mar}$ \\
\hline
\end{tabular}

TABLE 2

List of varieties used in the experiments. Year of accession to NIAB Recommended List for winter (W) or spring (S) variety is shown. The vernalisation response $(+)$ or non-response $(-)$ is indicated.

Liste des variétés utilisées dans les expérimentations avec indication de l'année d'inscription sur la 'NIAB Recommended List' pour les variétés d'hiver $(W)$ ou de printemps (S). La réaction $(+)$ ou non-réaction (-) à la vernalisation est indiquée.

\begin{tabular}{|c|c|c|c|c|c|}
\hline Barley & $\begin{array}{c}\text { NIAB } \\
\text { List }\end{array}$ & $\begin{array}{l}\text { Vernalisation } \\
\text { response }\end{array}$ & Wheat & $\begin{array}{c}\text { NIAB } \\
\text { List }\end{array}$ & $\begin{array}{l}\text { Vernalisation } \\
\text { response }\end{array}$ \\
\hline Athene & $1977 \mathrm{~W}$ & + & Aquila & $1979 W$ & + \\
\hline Igri & $1977 \mathrm{~W}$ & + & $1772 / 8$ & W & + \\
\hline Maris Otter & $1965 \mathrm{~W}$ & + & Avalon & $1980 \mathrm{~W}$ & + \\
\hline Kiruna & W & - & Fenman & $1982 W$ & - \\
\hline Sonja & $1975 \mathrm{~W}$ & + & Highbury & $1978 S$ & - \\
\hline Halcyon & W & + & Huntsman & $1972 W$ & + \\
\hline Crosier & W & + & Norman & $1981 \mathrm{~W}$ & + \\
\hline HJ51/2 & W & + & Wembley & $\mathrm{S}$ & - \\
\hline WB80/1 & W & + & Talent & $* W$ & + \\
\hline WB7/2 & W & + & & & \\
\hline WB32/1 & W & + & & & \\
\hline Ark Royal & $1976 \mathrm{~S}$ & - & & & \\
\hline
\end{tabular}

(source : NIAB recommended varieties of cereals 1983, and NSDO (1983) and anecdotal evidence). * Recommended in France since 1973. 
The main treatment was sowing date with 2 blocks for each of the 4 dates. Each block was divided into 2 sub-blocks within which the 9 variety plots were fully randomised. Thus within each sowing date there were 4 replications for variety.

The soil type where the experiments were done was a sandy loam overlying river gravel. Seeds were handsown, evenly spaced in rows $76 \mathrm{~mm}$ wide, at a density of 258 seeds $\mathrm{m}^{-2}$. Seedling establishment was generally more than 90 per cent. A top dressing of nitrogen fertiliser ( $75 \mathrm{~kg} \mathrm{~N}^{-1}$ ) was applied when most varieties in a sowing date treatment had reached terminal spikelet stage. Plant diseases and pests were controlled when necessary. Temperature data for the experiments were obtained from thermometers sited in a Stevenson screen, $2 \mathrm{~m}$ above ground level in the Institute weather station, less than $200 \mathrm{~m}$ from the experimental site (fig. 1).

The measurements of number of emerged leaves were part of a full developmental analysis and were made on plants removed from the plot. Sample plants were taken only from areas of full establishment such that each plant was surrounded by 8 intact neighbours, and proceeding systematically through the plot leaving adequate discard plants at the edge of the plot and between sampling places. One or two samplings were made each week depending on temperature and at each sampling one plant per variety per replicate was taken viz. 4 plants per variety. The number of emerged leaves was counted on the main shoot and a leaf was defined as having emerged when the tip of the lamina was visible above the uppermost auricles of the subtending leaves. Generally, counts continued from seedling emergence until ear emergence, but in the first sowing in some seasons leaf death made it difficult to make reliable counts in the later stages of the life cycle and counting stopped before ear emergence. In all sowings total number of leaves per main shoot was determined by dissection, counts being made after the collar was clearly recognisable and before leaf death made total leaf number counts difficult. The total number of leaves was estimated from 15 to 30 plants for wheat and 20 to 60 plants for barley.

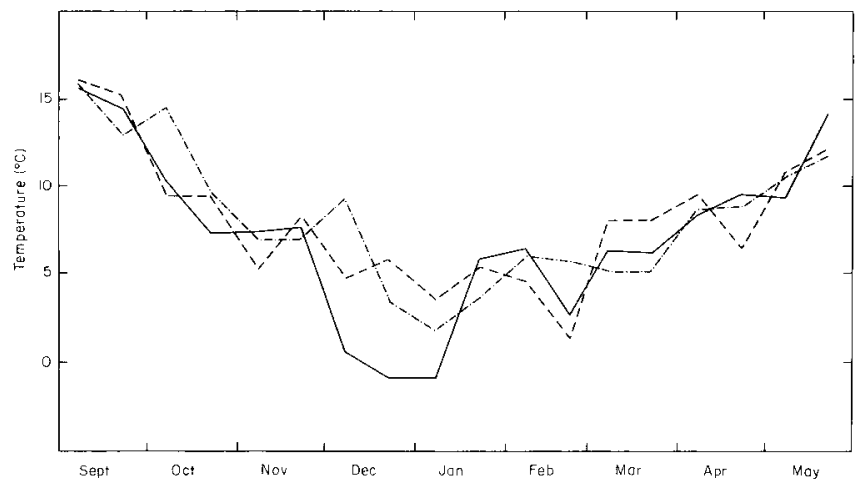

Figure 1

Mean daily temperature over 15-day periods for 1979/80 - - - - 1980/81 -.. and 1981/82

Température quotidienne moyenne par périodes de 15 jours pour 1979/80 -. - - $1980 / 81$--- and 1981/82 -.

\section{B. Analysis of rate using thermal time}

In order to compensate for seasonal fluctuations in temperature several workers (table 6) have analysed leaf emergence as a function of accumulated temperature (thermal time, heat units) (GALLAGHER, 1976). This analysis is based on the fact that the response to temperature of the rate of many botanical phenomena is linear over the range of normal field temperatures (c. $0-25^{\circ} \mathrm{C}$ ). At a certain temperature the rate is zero and this is usually referred to as the base temperature.

If these assumptions are correct, then when temperature above the 'true' base temperature is accumulated over time, there is a linear response of number or size (integral of the rate) to accumulated temperature. As the base temperature selected for calculation of accumulated temperature deviates from the 'true' base temperature there is a systematic deviation from a linear response. Based on these considerations, a regression technique may be used for the estimation of base temperature (GALLAGHER, 1976 ; DURAND et al., 1982). Accumulated temperature is calculated using a range of temperatures as the base and the temperature which gives a minimum residual in regression (or minimum $\mathrm{r}^{2}$ in correlation) analysis (SNEDECOR \& COCHRAN, 1972) is selected as the best estimate of base temperature.

\section{RESULTS}

\section{A. Number of leaves}

The greatest number of leaves was found on the main shoot in sowing 1 (table 3 ). The winter wheat varieties excluding 'Talent' $(1980 / 81)$ but including 'Fenman' formed either 14 or 13 leaves but spring varieties formed only between 12 and 10 leaves. With later sowing the number of leaves declined systematically to a minimum of between 11 and 9 in sowing 3 . In winter varieties (excluding 'Fenman') more leaves were formed in sowing 4 than in sowing 3, whereas in the spring varieties and 'Fenman' the number of leaves were least in sowing 4 .

The change in number of leaves with sowing date in barley was generally similar to that in wheat (table 3), but sowing 4 had less leaves than sowing 3 .

\section{B. Rate of leaf emergence}

When number of leaves for wheat was plotted against time it was clear that leaves emerged fastest the later the sowing date (e.g. 'Norman'. fig. 2). Thus there was a period from November until the end of April when sowings 1 and 2 could be compared and from mid-January until the end of April when sowing 1, 2 and 3 could be compared. During these times the rate at which leaves emerged in sowing 2 was faster than that in sowing 1 and leaves emerged faster in sowing 3 than either sowing 1 or 2 . Over the whole period there was considerable fluctuation in the rate of leaf emergence e.g. in sowing 1 the highest rates occurred in October and April, although leaf emergence continued, albeit at a slow rate, throughout the winter. 
TABLE 3

Modal number of leaves on the main shoot of wheat and barley sown over three years

Valeur modale du nombre de feuilles total formé sur le brin-maitre pour chaque combinaisonespèce $\times$ variété $\times$ date de semis $\times$ année - étudiée

\begin{tabular}{|c|c|c|c|c|c|c|c|c|}
\hline Wheat & \multicolumn{4}{|c|}{$\begin{array}{l}\text { 1980/81 } \\
\text { Sowing }\end{array}$} & \multicolumn{4}{|c|}{$\begin{array}{l}1981 / 82 \\
\text { Sowing }\end{array}$} \\
\hline & 1 & 2 & 3 & 4 & 1 & 2 & 3 & 4 \\
\hline Aquila & 14 & 11 & 11 & 11 & 14 & 12 & 10 & 13 \\
\hline Avalon & & & & & 13 & 12 & 11 & 12 \\
\hline Fenman & 13 & 11 & 11 & 10 & 13 & 12 & 11 & 9 \\
\hline Highbury & 11 & 11 & 10 & $8 / 9$ & 10 & 10 & 10 & 8 \\
\hline Huntsman & 14 & 11 & 11 & 11 & 14 & 12 & 11 & 12 \\
\hline Norman & 14 & 11 & 10 & 11 & 14 & 11 & 10 & 12 \\
\hline Wembley & 12 & 11 & 11 & 10 & 12 & 12 & 10 & 9 \\
\hline Talent & 12 & 11 & 9 & 10 & 13 & 11 & 9 & 11 \\
\hline Igri (barley) & 15 & 13 & 12 & 11 & 15 & 13 & 11 & 12 \\
\hline
\end{tabular}

\begin{tabular}{|c|c|c|c|c|c|c|c|c|}
\hline \multirow{2}{*}{$\begin{array}{l}\text { Barley } \\
\text { Variety }\end{array}$} & \multicolumn{4}{|c|}{$\begin{array}{l}\text { 1979/80 } \\
\text { Sowing }\end{array}$} & \multicolumn{4}{|c|}{$\begin{array}{l}1980 / 81 \\
\text { Sowing }\end{array}$} \\
\hline & 1 & 2 & 3 & 4 & 1 & 2 & 3 & 4 \\
\hline Athene & 14 & 13 & 12 & 10 & 15 & 12 & 11 & 9 \\
\hline Igri & 15 & 13 & 12 & 11 & 15 & 13 & 12 & 10 \\
\hline Maris Otter & 14 & 13 & 12 & 10 & & & & \\
\hline Kiruna & & & & & 14 & 12 & 12 & 9 \\
\hline Sonja & 14 & 13 & 12 & 10 & 15 & 12 & 12 & 10 \\
\hline Halcyon & 14 & 13 & 12 & 10 & 14 & 12 & 11 & 10 \\
\hline Crosier & 14 & 12 & 12 & 11 & 14 & 12 & 11 & 11 \\
\hline Ark Royal & 11 & 11 & 11 & 10 & 12 & 11 & 11 & 10 \\
\hline
\end{tabular}

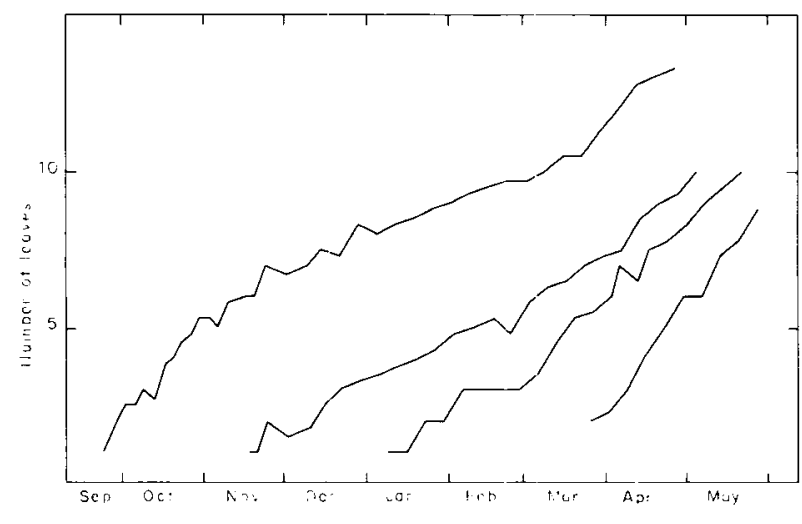

Figure 2

Number of emerged leaves on the main shoot for each of the four sowings for 'Norman' winter wheat in 1980/81.

Nombre de feuilles apparues sur le brin-maitre pour chacun des quatre semis pour le blé d'hiver 'Norman' 1980/81.

In barley, when number of leaves was plotted against time, a similar response to sowing date was found (KIRBY et al., 1982).

When number of leaves for varieties within a sowing was plotted against time it was seen that the rate of leaf emergence differed amongst varieties both in wheat and in barley (fig. 3). The differences were similar in each sowing.

\section{Variation of base temperature}

In analyses of wheat leaf emergence the base temperature is usually taken as $0{ }^{\circ} \mathrm{C}$ (table 6) and this generally gives a linear response, with any deviations

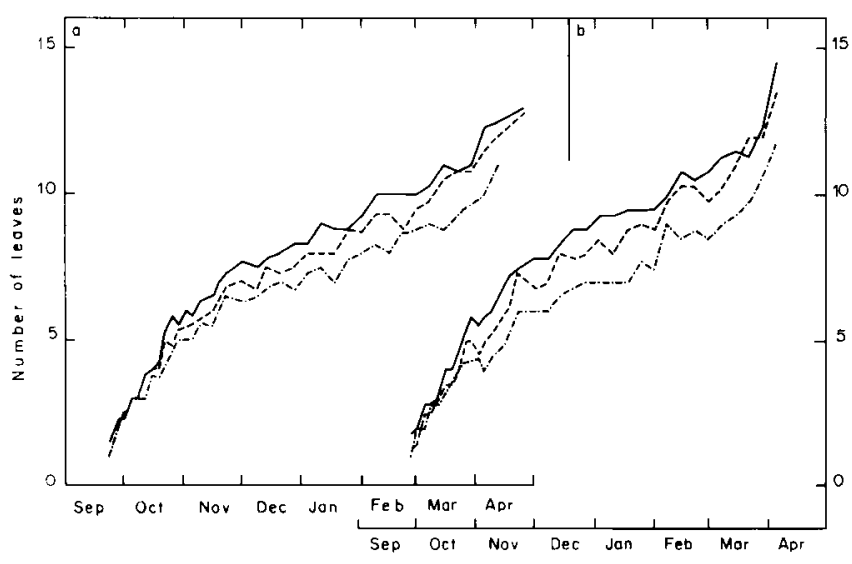

Figure 3

Number of emerged leaves on the main shoot against time (1980/81).

a) Wheat : - 'Huntsman' (winter type) ; --- 'Fenman' (alternative type); - - - 'Highbury' (spring type).

b) Barley: - 'Igri' (winter); -..- 'Sonja' (winter); - - - - 'Ark Royal' (spring).

Nombre de feuilles apparues sur le brin-maitre au cours du temps $(1980 / 81)$

a) Blé : - "Huntsman "(variété d'hiver); --- « Fenman " (variété alternative); - - - - "Highbury » (varieté de printemps);

b) Orge : - "Igri » (hiver); -- « Sonja " (hiver); - - - « Ark Royal » (printemps).

from the fitted line appearing to be random. It has been shown for barley that there appeared to be a systematic change in base temperature with sowing date (KIRBY et al., 1982). When the wheat data for sowing 1 of this experiment were plotted against accumulated temperature with base temperature $0^{\circ} \mathrm{C}$, 
although there was a highly significant regression, there was also a systematic deviation from a linear response (fig. 4). For values of accumulated temperature less than about 350 and above $850{ }^{\circ} \mathrm{Cd}$ the observed values were below those predicted by linear regression; from 350 to $850^{\circ} \mathrm{Cd}$ almost all the observed values were greater than predicted. Using $5^{\circ} \mathrm{C}$ instead of $0^{\circ} \mathrm{C}$ to calculate accumulated temperature maximised the $\mathrm{r}^{2}$ and there was no systematic deviation of the observed values about the fitted line (fig. 4).

The base temperature which maximised $r^{2}$ was determined for each variety of wheat in each sowing. There was no indication of any varietal differences in estimated base temperatures and the mean values over all varieties are given for each sowing in table 4 . In

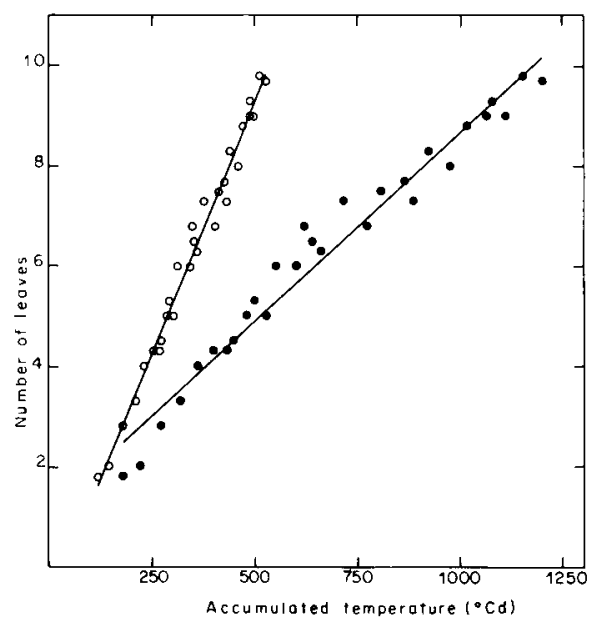

Figure 4

Number of emerged leaves on the main shoot of 'Norman' winter wheat from the September sowing 1981/82 against accumulated temperature from date of sowing. $\bullet$, base temperature $0^{\circ} \mathrm{C}$; $\checkmark$, base temperature $5{ }^{\circ} \mathrm{C}$. The lines were fitted by linear regression.

Relation entre le nombre de feuilles du brin-maître et la somme des températures cumulées depuis le semis (variété de blé d'hiver "Norman "; semis de septembre, 1981/82). •, température de base $0{ }^{\circ} \mathrm{C} ; \mathrm{O}$, température de base $5{ }^{\circ} \mathrm{C}$. Les droites correspondent aux ajustements obtenus par régression linéaire.

\section{TABLE 4}

Base temperature $\left({ }^{\circ} \mathrm{C}\right)$ and rates of leaf emergence (leaves $\left(100{ }^{\circ} \mathrm{C}\right.$ days) ${ }^{-1}$ ) estimated using the $r^{2}$ method (see text). Mean values over all wheat varieties for sowings 1 to 4, 1980/81 and 1981/82

Température seuil $\left({ }^{\circ} \mathrm{C}\right.$ ) et vitesse d'apparition des feuilles (nombre de feuilles $\left(100^{\circ} \mathrm{C}\right.$-jours) ${ }^{-1}$ ) estimées par la méthode $r^{2}$ (voir texte). Valeurs movennes toutes variétés de blé confondues pour les semis I à $4,1980 / 81$ et $1981 / 82$

\begin{tabular}{lcccc}
\hline \multicolumn{1}{c}{$1980 / 81$} & 1 & \multicolumn{4}{c}{ Sowing } \\
\hline Base temperature & 5.75 & -0.63 & 0 & 4 \\
Rate of leaf emergence & 1.97 & 0.90 & 1.07 & 0.96 \\
\hline
\end{tabular}

$1981 / 82$

\begin{tabular}{lllll}
\hline Base temperature & 5.67 & 0 & 0.11 & -3 \\
Rate of leaf emergence & 2.00 & 0.91 & 1.10 & 1.02 \\
\hline \hline
\end{tabular}

both years the estimated base temperature for the mid-September sowing (sowing 1) was about $5^{\circ} \mathrm{C}$, but fell to about $0{ }^{\circ} \mathrm{C}$ for the October and November sowings (sowing 2 and 3). Base temperature value for sowing 4 was estimated to be $-3^{\circ} \mathrm{C}$, but for this sowing the ambient temperature during the period of estimation was higher than the other sowings and considerable extrapolation was involved (see base temperature values for barley in KIRBY et al., 1982).

\section{Comparison of leaf emergence rate}

Although there was evidence of variation in base temperature in response to sowing date, very highly significant. In wheat there was a significant interaccumulated temperature were obtained using a constant base temperature over all sowings. Therefore for comparison between sowings and for comparison with results from other experiments further analysis was made using one base temperature $\left(0^{\circ} \mathrm{C}\right.$ for wheat, $1{ }^{\circ} \mathrm{C}$ for barley) over all sowings.

There was variation in rate of leaf emergence (on the basis of accumulated temperature) due both to sowing date and variety (table 5). Analysis of variance indicated that variation due to both these factors was significant. In wheat there was a significant interaction between variety and sowing date, but this was small in magnitude and accounted for a small proportion of the sum of squares. In barley the interaction between genotype and sowing date was not significant. In wheat the rate of leaf emergence of most varieties increased by about 70 per cent from sowing 1 to sowing 4 . In barley in $1979 / 80$ the average increase was about 80 per cent, but in $1980 / 81$ the increase was only about 45 per cent. The difference between varieties with the highest ('Huntsman') and lowest ('Highbury') rates in wheat was about 16 per cent, similar to differences ( 18 per cent) between the barley variety 'Sonja' with the fastest rate and the one with the slowest rate ('Ark Royal').

\section{E. Difference in rate of leaf emergence between wheat and barley}

Table 5 showed that the rate of leaf emergence in barley was generally higher than that of wheat. A direct comparison was possible in the wheat experiment, in which 'Igri' was included. In this comparison the rate of leaf emergence was higher for 'Igri' than for any of the wheat varieties (table 5).

\section{DISCUSSION}

\section{A. Effect of date of sowing}

The results confirm those of BAKER et al. (1980) and KIRBY et al. (1982) which showed that rate of leaf emergence responded strongly to date of sowing. BAKER et al. (1980) examined the factors which might elicit this response and established a strong correlation between rate of leaf emergence and rate of change of daylength (civil twilight to civil twilight) at the time of emergence of the first leaf. A similar relationship was found for barley (KIRBY et al., 1982). The 
TABLE 6

Summary of rates of leaf emergence in relation to rate of change of daylength at the time of plant emergence. In each case a base temperature of $0{ }^{\circ} \mathrm{C}$ was used to calculate accumulated temperature

Vitesses d'apparition des feuilles et d'évolution de la durée du jour au moment de la levée. Dans chaque cas, les températures cumulées ont été calculées pour une température de base de $0{ }^{\circ} \mathrm{C}$

\begin{tabular}{|c|c|c|c|c|c|}
\hline Reference & $\begin{array}{c}\text { Site } \\
\text { and } \\
\text { Latitude }\end{array}$ & Variety & $\begin{array}{c}\text { Date } \\
\text { of } \\
\text { plant } \\
\text { emergence }\end{array}$ & $\begin{array}{l}\text { Rate of } \\
\text { change of } \\
\text { daylength } \\
\text { hours/day }\end{array}$ & $\begin{array}{c}\text { Rate of } \\
\text { leaf } \\
\text { emergence } \\
\text { leaves } / 100^{\circ} \mathrm{Cd}\end{array}$ \\
\hline \multicolumn{6}{|l|}{ WHEAT } \\
\hline $\begin{array}{l}\text { Baker, Gallagher \& Monteith } \\
\text { (1980) }\end{array}$ & Loughborough $52^{\circ} 47^{\prime}$ & $\begin{array}{c}\text { Maris } \\
\text { Huntsman }\end{array}$ & $\begin{array}{ll}16 & \text { Oct } \\
21 & \text { Oct } \\
23 & \text { Nov } \\
22 & \text { Dec } \\
24 & \text { Mar } \\
13 & \text { Jun }\end{array}$ & $\begin{aligned}- & 0.064 \\
- & 0.062 \\
- & 0.041 \\
& 0.0 \\
& 0.069 \\
& 0.025\end{aligned}$ & $\begin{array}{l}0.69 \\
0.82 \\
0.91 \\
1.05 \\
1.31 \\
1.12\end{array}$ \\
\hline Delecolle \& Gurnade (1980) & Gréoux $43^{\circ} 45^{\prime}$ & Talent & $\begin{array}{l}15 \mathrm{Nov} \\
30 \mathrm{Dec}\end{array}$ & $\begin{array}{r}-0.035 \\
0.009\end{array}$ & $\begin{array}{l}0.96 \\
0.91\end{array}$ \\
\hline Hay \& Abbas Al-Ani (1983) & Lancaster $54^{\circ} 03^{\prime}$ & Hustler & $\begin{aligned} & 28 \text { Oct } \\
& 2 \mathrm{Dec} \\
& 20 \mathrm{Feb} \\
& 16 \mathrm{Mar}\end{aligned}$ & $\begin{array}{r}-0.064 \\
-0.033 \\
0.067 \\
0.073\end{array}$ & $\begin{array}{l}0.58 \\
0.98 \\
1.09 \\
1.06\end{array}$ \\
\hline $\begin{array}{c}\text { Hay \& } \\
(1982)\end{array}$ & Lancaster $54^{\circ} 03^{\prime}$ & Hustler & $\begin{array}{r}25 \mathrm{Oct} \\
23 \mathrm{Nov} \\
2 \mathrm{Mar}\end{array}$ & $\begin{array}{r}-0.065 \\
-0.045 \\
0.070\end{array}$ & $\begin{array}{l}0.98 \\
1.08 \\
0.98\end{array}$ \\
\hline \multicolumn{6}{|l|}{ BARLEY } \\
\hline Ellis \& Russell* (1983) & Roslin, Lothian $55^{\circ} 51^{\prime}$ & $\begin{array}{l}\text { G. Promise } \\
\text { Maris Otter } \\
\text { G. Promise } \\
\text { Maris Otter } \\
\text { G. Promise } \\
\text { Maris Otter } \\
\text { G. Promise } \\
\text { Maris Otter }\end{array}$ & $\begin{aligned} 24 & \text { Oct } \\
24 & \text { Oct } \\
2 & \text { Dec } \\
2 & \text { Dec } \\
7 & \text { Apr } \\
7 & \text { Apr } \\
11 & \text { May } \\
11 & \text { May }\end{aligned}$ & $\begin{array}{r}-0.071 \\
-0.071 \\
-0.036 \\
-0.036 \\
0.082 \\
0.082 \\
0.079 \\
0.079\end{array}$ & $\begin{array}{l}0.9 \\
0.9 \\
1.3 \\
1.3 \\
1.8 \\
1.5 \\
1.4 \\
1.0\end{array}$ \\
\hline $\begin{array}{r}\text { Fairey, } \\
(1975)\end{array}$ & Controlled environment & Fergus & $\begin{array}{l}12 \mathrm{~h} \text { day } \\
24 \mathrm{~h} \text { day }\end{array}$ & - & $\begin{array}{l}1.00 \\
1.30\end{array}$ \\
\hline Kirby \& Eisenberg (1966) & Controlled environment & Proctor & $\begin{array}{l}12 \mathrm{~h} \text { day } \\
15 \mathrm{~h} \text { day } \\
18 \mathrm{~h} \text { day }\end{array}$ & $\begin{array}{l}- \\
-\end{array}$ & $\begin{array}{l}0.79 \\
0.95 \\
1.15\end{array}$ \\
\hline \multirow[t]{3}{*}{ Kirby \& Ellis (1980) } & $\begin{array}{l}\text { Trumpington, Cambridge } \\
52^{\circ} 11^{\prime}\end{array}$ & $\begin{array}{l}\text { Golden } \\
\text { Promise }\end{array}$ & $\begin{array}{l}12 \mathrm{Apr} \\
20 \mathrm{Apr}\end{array}$ & $\begin{array}{l}0.070 \\
0.070\end{array}$ & $\begin{array}{l}1.20 \\
1.73\end{array}$ \\
\hline & $\begin{array}{c}\text { Pathhead } \\
\text { Lothian } 55^{\circ} 53^{\prime}\end{array}$ & $\begin{array}{c}\text { Maris Mink } \\
\text { Golden } \\
\text { Promise }\end{array}$ & $\begin{array}{l}12 \mathrm{Apr} \\
20 \mathrm{Apr} \\
16 \mathrm{Apr} \\
27 \mathrm{Apr}\end{array}$ & $\begin{array}{l}0.070 \\
0.070 \\
0.083 \\
0.083\end{array}$ & $\begin{array}{l}1.19 \\
1.41 \\
1.55 \\
1.76\end{array}$ \\
\hline & & Maris Mink & $\begin{array}{l}16 \mathrm{Apr} \\
27 \mathrm{Apr}\end{array}$ & $\begin{array}{l}0.083 \\
0.083\end{array}$ & $\begin{array}{l}1.46 \\
1.48\end{array}$ \\
\hline Kirby \& Faris (1972) & Cambridge $52^{\circ} 11^{\prime}$ & Proctor & 24 Apr & 0.070 & 1.38 \\
\hline $\begin{array}{l}\text { Russell, Ellis, Brown, } \\
\text { Milbourn \& Hayter (1982) }\end{array}$ & Pathhead, Lothian $55^{\circ} 53^{\prime}$ & $\begin{array}{l}\text { G. Promise } \\
\text { Maris Otter } \\
\text { G. Promise } \\
\text { Maris Otter }\end{array}$ & $\begin{array}{r}10 \text { Noy } \\
10 \text { Nov } \\
5 \text { May } \\
5 \text { May }\end{array}$ & $\begin{array}{r}-0.061 \\
-0.061 \\
0.081 \\
0.081\end{array}$ & $\begin{array}{l}1.13 \\
1.21 \\
1.29 \\
1.34\end{array}$ \\
\hline
\end{tabular}

* Dates of plant emergence estimated from average temperature at time of sowing, using $100^{\circ} \mathrm{Cd}$ from sowing to emergence.

Some variation in base temperature for leaf emergence between sowings was shown by GALLAGHER (1976) but it was small compared with the variation found in both wheat and barley, cported in this paper. The biggest change in base temperature was found between the September sowing and the later sowings (table 4 and table 5 in KIRBY et al., 1982). Comparable early sowings were not made by GALLAGHER. The estimation of base temperature depends upon the selection of a maximum $r^{2}$, but the variation in $\mathbf{r}^{2}$ with base temperature is small (KIRBY et al., 1982). The technique also assumes a similar response to temperature over all leaves, but there is some evidence of ontogenetic changes in the rate of leaf appearance (BLONSTEIN, 1982).

All the data summarised here clearly establish that there is considerable variation in the rate of leaf appearance with date of sowing, which is unrelated to variation in temperature. For purposes of analysis or prediction of leaf emergence the use of accumulated 
temperature provides a satisfactory technique and the significant correlation with rate of change of daylength enables allowance to be made for date of sowing. However, there are uncertainties about the control of this phenomenon which probably cannot be resolved by statistical techniques used in this paper and will require experimentation with controlled variation of such factors as rate of change of daylength to elucidate them.

\section{B. Varietal differences in number of leaves and leaf emergence rate}

Much of the interaction between variety and sowing date for number of leaves on the main shoot can be explained by differences in vernalisation response. The true winter varieties e.g. 'Huntsman', which have a marked vernalisation response (NSDO, 1983) had the highest number of leaves in sowing 1 . In this sowing, leaf initiation rates were high and plants made considerable leaf growth during the warm weather of late September and October when the average daily temperature was above $10^{\circ} \mathrm{C}$ and vernalisation proceeded slowly. In the October and November sowings, the rate of leaf initiation and growth were slower in the lower temperatures and the vernalisation requirement was satisfied in the small seedling, with a consequent reduction in number of leaves. In sowing 4, particularly the March sowing in 1981/82 the higher temperature during seedling stage again led to a higher number of leaves in the winter varieties. In contrast, the spring varieties e.g. 'Highbury', which have little or no vernalisation response the number of leaves differs less between sowing 1, 2 and 3 . In sowing 4 there was a further reduction in number of leaves in response to the longer daylength at seedling emergence. 'Fenman' which is known to have no vernalisation response (NSDO, 1983) had more leaves in sowing 1 , like the winter varieties, but leaf number was low in sowing 4 . There were differences in leaf number between varieties with a similar response to sowing date e.g. 'Huntsman' and 'Talent'.

Unlike number of leaves, the rate of leaf emergence showed either no variety $x$ date of sowing interaction or, in wheat, it was small in magnitude and accounted for only a small portion of variation. Therefore the observed relative differences are likely to be maintained irrespective of sowing date.

In both wheat and barley the true winter varieties e.g. 'Norman' and 'Sonja' tended to have the higher rates and in both species a spring type ('Highbury' and 'Ark Royal') had the lowest rates. However, this may not be general ; the number of varieties examined was small and amongst the wheats the spring variety 'Wembley' had a rate comparable to the winter varieties.

It is clear from the results presented in this paper and from the other papers cited that date of sowing and variety affects the production of leaves in a complex way. In addition to number of leaves per shoot and rate of leaf emergence, leaf size may be affected (GAllaGHER, 1976 ; KIRBY et al., 1982) and there may be interactions between these characters. In addition, rate of leaf emergence and final number of leaves per shoot affects the rate at which tillers are produced and the maximum number of tillers (KIRBY et al., 1985). The differences in leaf characters will probably affect the development of the leaf canopy, but it is not easy to deduce what the effect may be because, in addition to variation in leaf parameters with variety and sowing date, temperature and daylength also vary with sowing date. To ascertain if these changes in leaf parameters have any adaptive or yield advantages further research is necessary.

Reçu le 19 janvier 1984. Accepté le 21 septembre 1984.

\section{REFERENCES}

Baker C. K., Gallagher J. N., Monteith J. L.. 1980. Daylength and leaf appearance in winter wheat. Plant, Cell and Environment, 3, 285-287.

Blonstein A. D., 1982. Developmental and genetic analysis of new dwarf mutants in barley, Hordeum vulgare and their potential for incorporation into short strawed commercial varieties. $\mathrm{PhD}$ thesis, Univ. Cambridge, 145 p.

Delecolle R., Gurnade J. C., 1980. Liaisons entre le développement et la morphologie du blé tendre d'hiver. I. Stades de développement de l'apex, apparition des feuilles et croissance de la tige. Ann. Amélior. Plantes, 30 (4), 479-498.

Durand R., Bonhomme R., Derieux M.,1982. Seuil optimal des sommes de températures. Application au mais (Zea mays L.). Agronomie, 2 (7), 589-597.

Edwards K. J. R., Cooper J. P., 1963. The genetic control of leaf development in Lolium. II. Response to selection. Heredity, 18, 307-317.

Ellis R. P., Russell G., 1983. Plant development and grain yield in spring and winter barley. J. Agric. Sci., Camb., 102, 85-95.

Fairey D. T., Hunt L. A., Stoskopf N. C., 1975. Daylength influence on reproductive development and tillering in Fergus barley. Can. J. Bot., 53, 2770-2775.
Gallagher J. N., 1976. The growth of cereals in relation to weather. PhD thesis, Univ. Nottingham, $171 \mathrm{p}$.

Haun J. R., 1973. Visual quantification of wheat development. Agron. J., 65, 116-119.

Hay R. K. M., Abbas Al-Ani M. K., 1983. The physiology of forage rye (Secale cereale). J. Agric. Sci., Camb., 101, 63-70.

Hay R. K. M., Tunnicliffe Wilson G., 1982. Leaf appearance and extension in field-grown winter wheat plants : the importance of soil temperature during vegetative growth. J. Agric. Sci., Camb., 99, 403-410.

Kirby E. J. M., Appleyard M., Fellowes G., 1982. Effect of sowing date on the temperature response of leaf emergence and leaf size in barley. Plant, Cell and Environment, 5, 477-484.

Kirby E. J. M., Appleyard M., Fellowes G., 1985. Leaf emergence and tillering in barley and wheat in response to variety and date of sowing. Agronomie, 5 (3), 000-000.

Kirby E. J. M., Eisenberg B. E., 1966. Some effects of photoperiod on barley. J. Exp. Bot., 17, 204-213.

Kirby E. J. M., Ellis R. P., 1980. A comparison of spring barley grown in England and in Scotland. 1. Shoot apex development. $J$. Agric. Sci., Camb., 95, 101-110. 
Kirby E. J. M., Faris D. G., 1972. The effect of plant density on tiller growth and morphology in barley. J. Agric. Sci., Camb., 78 281-288.

NSDO, 1983. Wheat. A guide to varieties from the Plant Breeding Institute. National Seed Development Organisation Ltd., Newton, Cambridge, $58 \mathrm{p}$.

Porter J. R., Bragg P. L., Rayner J. H., Weir A. H., Landsberg J. J., 1982. The ARC winter wheat simulation model. In : Opportunities for Manipulation of Cereal Productivity, Monograph 7 (eds. A. F. Hawkins \& B. Jeffcoat), British Plant Growth Regulator Group, Wantage UK, 97-108.

Russell G., Ellis R. P., Brown J., Milbourn G. M., Hayter A. M.,
1982. The development and yield of autumn- and spring-sown barley in south east Scotland. Ann. Appl. Biol., 100, 167-178.

Snedecor G. W., Cochran W. G., 1972. Statistical Methods. Iowa State University Press, Ames, Jowa, 593 p.

Syme J. R., 1974. Leaf appearance rate and associated characters in some Mexican and Australian Wheats. Aust. J. Agric. Res., 25, $1-7$.

Willington V. B. A., Biscoe P. V., 1983. Effects of nitrogen on growth and development of winter wheat. In : $M A F F$ Reference Book 385. The nitrogen requirement of cereals. Proceedings of a conference organised by the Agricultural Development and Advisory Service, September 1983. HMSO, London, 131-132. 